\title{
Scientific Inquiry Competency Perception Scale (The Case of Kazak Post- Graduate Students) Reliability and Validity Study
}

\section{Yücel Gelișli}

Prof., Gazi University, Gazi Faculty of Education, Department of Educational Sciences, Turkey,ygelisli@gmail.com

\section{Lyazzat Beisenbayeva}

L. N. Gumilyov Eurasian National University, Philology Faculty, Kazakhstan,

aishalyaz@mail.ru

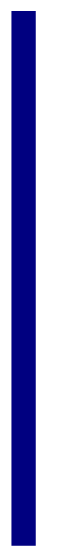

The purpose of the current study is to develop a reliable scale to be used to determine the scientific inquiry competency perception of post-graduate students engaged in post-graduate studies in the field of educational sciences and teacher education in Kazakhstan. The study employed the descriptive method. Within the context of the study, a scale was developed to determine the scientific inquiry perception of post-graduate students from the field of educational sciences and teacher education, then it was piloted and the validity and reliability studies of the scale were conducted. The study was conducted on 100 post-graduate students having post-graduate education in the field of education sciences and teacher education at four different Kazak state universities. The findings of the study revealed that the Scientific Inquiry Competency Perception Scale (SICPS) is comprised of four sub-factors (Problem Statement, Measurement Tool, Data Analysis, Reporting) and is a reliable and valid data collection tool $(\alpha=0,958)$ that can be used in future research to determine scientific inquiry competencies.

Key Words: scientific inquiry, competency perception, competencies, perception, perception scale

\section{INTRODUCTION}

Fast development of science and technology, particularly as of the 20th century has brought about important changes in our lives. The idea that knowledge is unchangeable has been ruled out in this century and new information and technologies have come to our lives in different states and with different applications. As a result of fast changes and developments taking place in the world of science and technology, the demand for individuals who can adjust to innovations, can consider events from different perspectives, are productive, can make inquiry and develop themselves has been increasing. 
Since their first existence, humans have felt the need for understanding the universe and its mysteries and controlling the nature. On the basis of this need, those attempting to define the science have come up with two views of science different from each other in terms of their focus on theory or practice. The proponents of the first view emphasized the importance of theory. The theory-based view attached the highest priority to understanding the universe and according to this view, science can be defined as academic endeavours taken and knowledge developed by humans to understand the universe and natural phenomena and the relationships between them. According to the second view, that is, those emphasizing practice, science can be defined as technical inventions facilitating human life (Kaptan, 1993: 6-7).

The main objective of science is to elicit the relationships between phenomena through observations and experiments, justify these relationships and then generalize them and finally to reach theories and laws on the basis of these generalizations. Thus, science can accomplish its objective by using scientific method. Scientific method makes up the process dimension of science. The most important basis of the developments occurring in the field of science and technology is without doubt scientific research. Scientific research refers to all information production activities performed regarding the determination of the problems, planning of solutions, and application of them, concluding them and discussion and interpretation of the results (Yenilmez, Ata, 2012).

Scientific research is a term with extensive meaning covering a process including developing a hypothesis, collecting and analysing data related to the hypothesis, testing of the hypothesis and reporting of the results through a systematic and rigorous study (Boudah, 2011).

According to the Turkish Language Association (TDK, 2016), Research is defined as the process of collection, analysis, interpretation and reporting of data in a systematic and reliable way to create reliable solutions to problems.

Research is a multiple-stage process of enhancing our understanding of a topic or an issue, collecting information and analysing it. In research, generally there are five stages following each other. This is defined as the process of scientific method. In the solution of problems, this five-stage scientific method is applied. These are the definition of the problem, making observations, developing the hypothesis, trail of the hypothesis and reporting the results (Morrell, Carroll, 2010).

Through research, we can produce, develop and store information for the solution of our problems. This information helps us to understand problems we are confronted with more easily. In this regard, an analogy between the researcher and the mason can be made, like a mason continuously putting bricks throughout the process on the wall to create a strong wall from these bricks (Creswell, 2012: 3).

As can be understood from the above-given explanations, research is comprised of the stages of definition of the problem, determination of the research method suitable for the solution of the problem, collection of data in compliance with the problem, analysis of the data on the basis of the research problem, creation of a solution to the research problem and writing of the research report for the purpose of coming up with a solution 
to a problem. Thus, the successful completion of the research process depends on the scientific inquiry skills to be possessed by researchers. In order to conduct an inquiry, some certain knowledge, skills and competencies should be possessed.

Technical competencies required to conduct research involve knowledge and skills necessary for the systematic and careful execution of scientific analysis method (Erdem, 2012). Educational organizations are expected to fulfill the responsibility for imparting information, skills and competencies related to scientific process. Educational organizations should put forth efforts to impart these characteristics to their students according to their developmental levels. In recent years, higher education institutions have incorporated the course of Scientific Research Methods into their curriculums to develop their students' knowledge and skills to find solutions to their daily problems (Yaşar, 2014:110).

While conducting research entails a certain level of expertise, making use of the existing research, feeling inspired of it and contributing to it require a general research culture. The education organized for the purpose of inculcating these skills and competencies in relation to the general culture and expertise in researchers is called "research education". On the basis of this research education lays the ability of acquiring and demonstrating scientific methods and technical knowledge, skills and attitudes required by them and recognizing their place in personal and social life (Erdem, 2012).

Büyüköztürk and Köklü (1997) also viewed the inculcation of the research culture in students as an educational issue and defined research education as a type of education aiming to develop an awareness of research in the individual and the society by imparting scientific attitudes and behaviors and competencies concerning the field of inquiry to individuals. This education requires the integration of the disciplines of research techniques, statistics, measurement and evaluation and computer competency.

Post-graduate students are expected to have acquired the competencies required to conduct research. Post-graduate students should have knowledge about how to conduct research and competencies necessary for the direct application of this knowledge. In other words, post-graduate students having competencies to conduct research should be able to propose scientific solutions to educational problems by effectively using their inquiry skills in their academic research. Moreover, an academician should continuously improve himself/herself during a process of rapid development of science and technology. Thus, he/she must be sensitive towards scientific developments in his/her field and closely follow these developments. Further, academicians will be able to use scientific competencies acquired during their post-graduate education while conducting their scientific research and seeking solutions to educational problems (Kart, Gelbal, 2012). Thus, investigation of the extent to which post-graduate students have acquired scientific research competencies during their post-graduate education and gathering their opinions about these competencies are of great importance.

In order to enhance post-graduate students' scientific research competencies, there are courses of scientific research methods and statistical analysis in master's and doctorate programs. The objective of such courses is to inculcate basic knowledge and skills 
pertinent to scientific research competencies and positive attitudes towards scientific research and researchers in students. The courses of scientific research methods and statistical analysis address the topics such as science and its basic concepts (phenomenon, information, absolute, correct, false, universal knowledge etc.), basic information about history of science, scientific methods and different opinions about these methods, problem, research model, population and sampling, data collection and data collection methods (qualitative and quantitative data collection methods), recording of the data, data analysis, data interpretation and reporting (Yenilmez, Ata, 2012).

In post-graduate programs offered in the field of educational sciences and teacher education in Kazakhstan, there are different courses with varying class hours, contents and names provided for post-graduate students to acquire and develop their scientific inquiry competencies. The general objective of these courses is to systematically establish students' knowledge about scientific inquiry methodology and methods, to present the important issues of pedagogy within scientific courses and experimental activities, to form post-graduate students' professional pedagogic culture and to prepare them for finding solutions to professional problems. The contents of these courses include topics such as theoretical and methodological basis of pedagogical research, main methods of scientific research and their techniques, classification of research methods and reporting of their results and their implications and writing and defending a dissertation (Taubayeva, 2014).

In the studies of scholars such as Bogolovski, Zagvizanski, Zimni, Novikov and Yakovlev, it has been reported that there are problems experienced in complex research studies in education in Kazakhstan and this indicates scientific shortcomings in research studies (Sadvakazkızı et al., 2014: 45). Determination of the scientific inquiry competencies of post-graduate students working in the field of educational sciences and subject matter in Kazakhstan is believed to be very useful for future studies.

\section{The Purpose of the Study}

The purpose of the current study is to develop a reliable scale to be used to determine the scientific inquiry competency perception of post-graduate students engaged in postgraduate studies in the field of educational sciences and teacher education in Kazakhstan. To this end, answers to the following questions were sought:

1. What are the results of the explanatory factor analysis of Scientific Inquiry Competency Perception Scale (SICPS)?

2. What are the results of the reliability test of Scientific Inquiry Competency Perception Scale (SICPS)?

\section{METHOD}

\section{Research Design}

The current study is a descriptive study. Within the context of the study, it was aimed to develop a scale to determine the scientific inquiry perception of post-graduate students 
from the field of educational sciences and teacher education, then to pilot it and conduct its validity and reliability studies.

\section{Scale Development Group}

In the current study, for the purpose of developing a scale, a study group consisting of 100 post-graduate students randomly selected from among the post-graduate students attending post-graduate programs in the field of educational sciences and subject matter in four different universities (Avrasya University, Abay University, Pavlador University and Ahmet Yesevi University) located in four different cities of Kazakhstan in 20152016 academic year was used. Of these 100 students, 67 are females and 33 are males and 69 of them are master's students and 31 are doctorate students.

In Kazakhstan the field of educational sciences is made up of a single scientific discipline, it is not organized in the form of separate disciplines and a limited number of students are accepted into the post-graduate education. All of these reasons forced us to keep the size of the study group small. Moreover, hugeness of the country's geography made it very difficult to reach students from the fields of educational sciences and subject-area education

As the size of the population for the current study is not adequate, it became a must to administer the scale in a group of 100 participants. When the literature is examined, it can be seen that there are studies conducted in a similar situation. According to Sapnaz (2004), in case of inadequate population size, a sampling consisting of 100-250 participants can be enough. Traditional sampling sizes are more effective in determining scales' factor structures; however, according to the literature, the sampling size of the current study was determined to be sufficient to derive descriptive and experimental results (MacCallum, at. All, 1999. Sapnas, 1999. Sapnas, Zeller, 2002. Sapnas, 2004).

\section{Scale Development Process}

In the literature, it is reported that for developing a scale, certain stages should be followed. In the current study, scale development stages given below were followed (Cohen, Swerdlik, 2013; Crocker, Algina, 1986; DeVellis, 2014; Seçer, 2015; Şeker, Gençdoğan, 2014):

- Setting the goal of scale and determining to whom and why it will be administered

- Deciding the scope and content of the scale

- Writing items within the framework of the determined scope and content

- Item control and developing scale form

- Determining the scoring method of the items and analysis method of the data

- Administration of the scale to the scale development group

- Scoring and analysis of the items.

- Formation of the actual scale on the basis of the obtained results. 
In the current study, it was aimed to develop SCIPS by following the stages given above.

\section{Data Collection Tool}

By reviewing the literature, the draft Scientific Inquiry Competency Perception Scale (SICPS) was developed, then it was submitted to the scrutiny of three experts working in the field of educational sciences and measurement and evaluation and in light of their opinions, final form of the draft scale to be piloted was given. Before piloting, there were 71 items in the draft scale. The scale was organized in the form of five-point Likert scale as "never, partially, moderately, considerably and completely". The details of the reliability and validity studies of the scale are given in the findings section.

\section{Data Analysis}

The collected data were analyzed through IBM-SPSS 23 program. In order to determine the validity and reliability of SICPS, techniques such as Kaiser-Meyer-Olkin (KMO) test, Bartlett Sphericity test, varimax rotation, Cronbach Alpha reliability coefficient were employed (Büyüköztürk, 2013; Özdamar, 2013). The extent to which each item in the scale is adequate in discriminating students' perception was analyzed by using t-test to test the significance of the difference between the item scores of the top $27 \%$ and bottom $27 \%$ of the participants.

\section{FINDINGS}

Findings related to construct validity of Scientific Inquiry Competency Perception Scale (SICPS) in measurement and evaluation (validity and reliability)

In order to explain the structure of the scale, explanatory factor analysis was administered. In this analysis, Kaiser-Meyer-Olkin (KMO) and Bartlett Sphericity test were conducted to determine whether the dataset is suitable for factor analysis and then Varimax Rotation was run to reveal under which dimensions the items are subsumed and then how much of the variance of the characteristic under investigation (Scientific Inquiry Competency Perception) is explained by the emerging sub-dimensions was determined (Büyüköztürk, 2013; Özdamar, 2013). As a result of the analysis, KMO value of SICPS was found to be 0.874 . As this value is over 0.50 , it means that the dataset is suitable for factor analysis. Bartlett test result was found to be $X^{2}=2474,118$; $\mathrm{sd}=496(\mathrm{p}<0.01)$. The significance of the value obtained as a result of the Barlett test indicates that factor analysis can be conducted and the sampling size is enough (Büyüköztürk, 2013, Akgül, 1997: 581). It was concluded on the basis of the results of these two tests that the conducted factor analysis operations are suitable means of analysis for the collected data.

In the explanatory factor analysis, in order to determine whether there are subdimensions in the scale and if there are any, which items are gathered under which subdimensions, Varimax rotation was administered to the data set (Büyüköztürk, 2013; Özdamar, 2013). As the bottom cut point of the factor loadings, 0.30 was taken as the criterion. As a result of the principal components analysis conducted by using Varimax rotation, four factors with eigenvalues higher than 1 were obtained. The eigenvalue of 
the first factor is 8.260 and explains $25.81 \%$ of the total variance; the eigenvalue of the second factor is 5.104 and explains $15.94 \%$ of the total variance, the eigenvalue of the third factor is 3.772 and explains $11.78 \%$ of the total variance and the eigenvalue of the fourth factor is 3.082 and explains $9.63 \%$ of the total variance. These four factors together explain $63.17 \%$ of the total variance. Thus, the scale has a four-factor structure. These factors can be seen more clearly in the scree plot presented in Figure 1. Keeping the factor number high increases the explained variance yet makes it more likely to experience difficulties in naming them and making sense of them (Büyüköztürk, 2013). The higher the variance ratios obtained from the analysis are, the stronger factor structure is. In social sciences, when this ratio is between $40 \%$ and $60 \%$, then it is considered to be acceptable (Tavşanc1l, 2002:48).

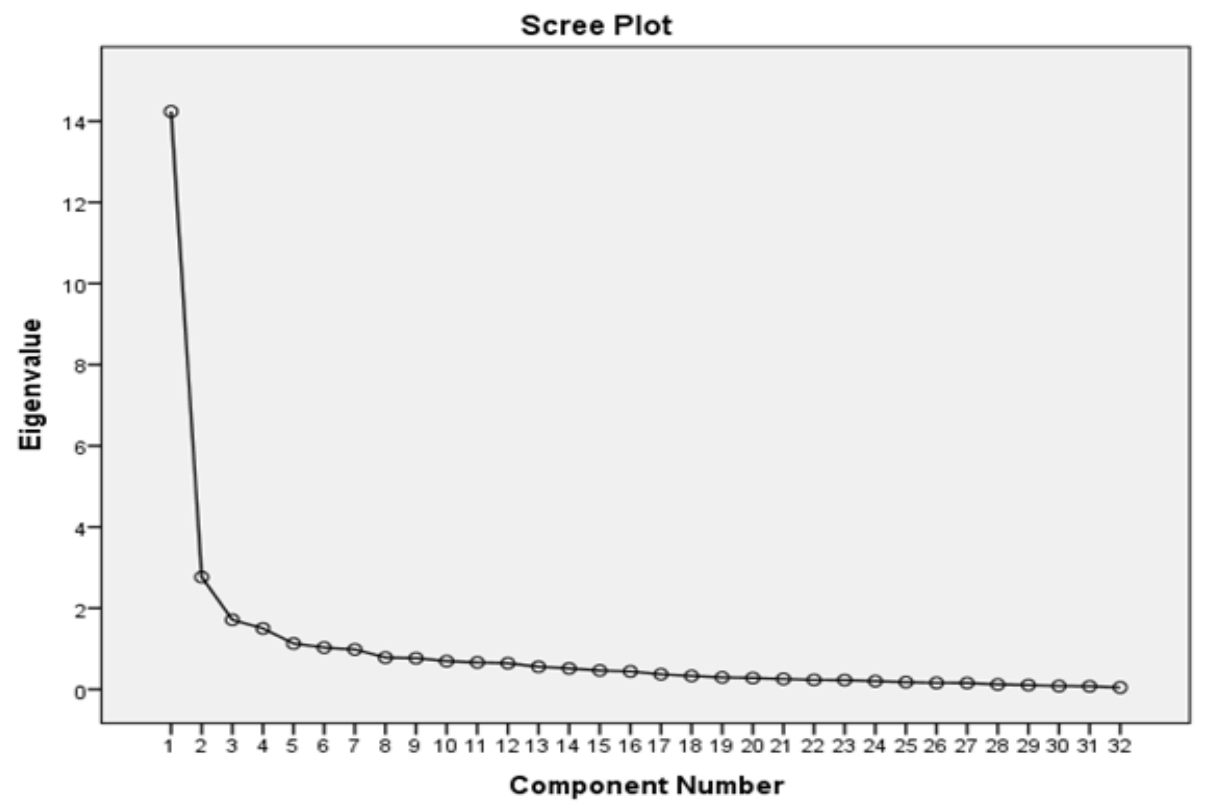

Figure 1

Scree plot of the factors emerging from the factor analysis

As a result of the exploratory factor analysis, item total correlations of the items remaining in the scale are seen to be varying between 0.423 and 0.784 . The scale was found to be consisting of four factors and the total variance explained by these four factors is $63 \%$. This value is accepted to be adequate in scale development studies in social sciences. Prior to the factor analysis, item total correlations were examined. As their item total correlations are lower than 0.30, they do not make any contributions to the scale and overlap (in more than one factor), items A2, A3, A4, A5, A8, A11, A12, A13, A14, A15, B1, B2, B3, B4, B5, B6, B7, B8, B9, B12, B16, B17, B18, B19, B22, 
B23, B24, B25, B29, C1, C2, C4, C6, C7, C8, C9, D1, D3 and E1 were discarded from the scale. Statistical information about the remaining 32 items is given in Table 1.

Table 1

SICPS' exploratory factor analysis and reliability analysis results

\begin{tabular}{|c|c|c|c|c|c|c|c|}
\hline \multirow[t]{2}{*}{ Item No } & \multirow[t]{2}{*}{$\begin{array}{l}\text { Including } \\
\text { factor }\end{array}$} & \multirow{2}{*}{$\begin{array}{l}\text { Item total } \\
\text { correlation }\end{array}$} & \multirow[t]{2}{*}{$\begin{array}{l}\text { Bottom } \\
27 \% \text {-Top 27\% }\end{array}$} & \multicolumn{4}{|c|}{$\begin{array}{l}\text { Item Loading Values in Factors as a } \\
\text { result of rotation }\end{array}$} \\
\hline & & & & Fac. I & Fac. II & Fact. III & Fac. IV \\
\hline A1 & Factor 1 & 0,423 & $-4,457$ & 0,590 & & & \\
\hline A6 & Factor 1 & 0,522 & $-5,005$ & 0,610 & & & \\
\hline A7 & Factor 1 & 0,596 & $-6,470$ & 0,609 & & & \\
\hline A9 & Factor 1 & 0,512 & $-5,170$ & 0,664 & & & \\
\hline A10 & Factor 1 & 0,570 & $-6,075$ & 0,727 & & & \\
\hline B10 & Factor 2 & 0,582 & $-6,750$ & & 0,576 & & \\
\hline B11 & Factor 2 & 0,590 & $-6,826$ & & 0,705 & & \\
\hline B13 & Factor 2 & 0,579 & $-7,155$ & & 0,733 & & \\
\hline B14 & Factor 2 & 0,598 & $-7,493$ & & 0,776 & & \\
\hline B15 & Factor 2 & 0,535 & $-6,183$ & & 0,590 & & \\
\hline B20 & Factor 2 & 0,601 & $-6,974$ & & 0,691 & & \\
\hline B21 & Factor 2 & 0,641 & $-8,371$ & & 0,722 & & \\
\hline B26 & Factor 3 & 0,631 & $-7,242$ & & & 0,705 & \\
\hline B27 & Factor 3 & 0,611 & $-6,909$ & & & 0,681 & \\
\hline B28 & Factor 3 & 0,621 & $-6,979$ & & & 0,695 & \\
\hline C3 & Factor 3 & 0,598 & $-7,992$ & & & 0,598 & \\
\hline C5 & Factor 3 & 0,516 & $-5,780$ & & & 0,735 & \\
\hline ARY1 & Factor 4 & 0,725 & $-9,383$ & & & & 0,651 \\
\hline ARY2 & Factor 4 & 0,716 & $-9,488$ & & & & 0,582 \\
\hline ARY3 & Factor 4 & 0,712 & $-7,687$ & & & & 0,705 \\
\hline ARY4 & Factor 4 & 0,701 & $-9,488$ & & & & 0,810 \\
\hline ARY5 & Factor 4 & 0,638 & $-7,516$ & & & & 0,792 \\
\hline ARY6 & Factor 4 & 0,717 & $-8,749$ & & & & 0,768 \\
\hline ARY7 & Factor 4 & 0,691 & $-8,766$ & & & & 0,834 \\
\hline ARY8 & Factor 4 & 0,686 & $-6,532$ & & & & 0,795 \\
\hline ARY9 & Factor 4 & 0,646 & $-6,466$ & & & & 0,657 \\
\hline ARY10 & Factor 4 & 0,678 & $-6,252$ & & & & 0,736 \\
\hline ARY11 & Factor 4 & 0,727 & $-6,670$ & & & & 0,613 \\
\hline ARY12 & Factor 4 & 0,698 & $-6,814$ & & & & 0,643 \\
\hline D2 & Factor 4 & 0,741 & $-11,323$ & & & & 0,713 \\
\hline E2 & Factor 4 & 0,784 & $-10,974$ & & & & 0,586 \\
\hline E3 & Factor 4 & 0,715 & $-10,416$ & & & & 0,565 \\
\hline $\begin{array}{l}\text { KMO= } \\
\text { Cronba } \\
\text { Bartlett }\end{array}$ & 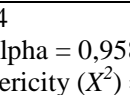 & & 0.01 & & & & \\
\hline
\end{tabular}

Moreover, in order to investigate how much the items in the scale differentiate individuals in the determination of the internal consistency, first corrected item total correlations were calculated and then t-test was run to determine the significance of the difference between the mean scores of the top $27 \%$ and bottom $27 \%$ groups. The corrected item correlations of the scale items vary between 0.423 and 0.784 . As a result of the t-test conducted to determine the significance of the difference between the top and bottom $27 \%$ groups, it was found that the difference between the two groups is significant at the level of $\mathrm{p}=.000$. 
The sub-factors of the Scientific Inquiry Competency Perception Scale and distribution of the items included in these factors:

- The items of the first sub-dimension are A1, A6, A7, A9 and A10. When the questions of the sub-dimension including these items were examined, it was found that they are related to the perception of the competency for developing the problem statement and expressing the problem used to initiate an inquiry. The items in this subdimension were renamed as P1, P2, P3, P4 and P5 and the dimension was named as "Problem Statement".

- The items of the second sub-dimension are B10, B11, B13, B14, B15, B20 and B21. When the questions of the sub-dimension including these items were examined, it was found that they are related to the perception of the competency for developing and using a measurement tool suitable for the purpose of the study. The items in this subdimension were renamed as ÖA1, ÖA2, ÖA3, ÖA4, ÖA5, ÖA6 and ÖA7 and the dimension was named as "Measurement Tool".

- The third sub-dimension was found to be comprised of items B26, B27, B28, C3 and C5. The questions of this sub-dimension were found to be related to the perception of competency for data analysis. The items in this sub-dimension were renamed as VA1, VA2, VA3, VA4 and VA5 and the sub-dimension was named as "Data Analysis".

- The items of the fourth sub-dimension are ARY1, ARY2, ARY3, ARY4, ARY5, ARY6, ARY7, ARY8, ARY9, ARY10, ARY11, ARY12, D2, E2 and E3. The items in this sub-dimension were found to be related to the perception of written reporting of the research and making it ready for presentation to the reader. The items in this subdimension were renamed as R1, R2, R3, R4, R5, R6, R7, R8, R9, R10, R11, R12, R13, $\mathrm{R} 14$ and R15 and the dimension was named as "Reporting".

\section{Findings related to reliability study of SICPS}

Reliability level for each of the four sub-dimensions was analyzed. The results of the analysis are given in Table 2.

Table 2

Cronbach Alpha test results related to the sub-dimensions of SICPS

\begin{tabular}{lll}
\hline Sub-dimension & Cronbach Alpha & Correlation \\
\hline $1^{\text {st }}$ Factor: Problem Statement & 0,800 & \\
\hline $2^{\text {nd }}$ Factor: Measurement Tool & 0,882 & \\
\hline $3^{\text {rd }}$ Factor: Data Analysis & 0,856 & \\
\hline $4^{\text {th }}$ Factor: Reporting & 0,955 & \\
\hline Total: & 0,958 &, 928 \\
\hline Spearman Brown Split Half Test Correlation & & \\
\hline
\end{tabular}

When Table 2 is examined, it is seen that the Cronbach Alpha reliability coefficient is $\alpha=0,800$, that of the second sub-dimension is $\alpha=0.882$, that of the third sub-dimension is $\alpha=0.856$, and that of the fourth sub-dimension is $\alpha=0.955$ and the Cronbach Alpha coefficient for the whole scale is $\alpha=0.958$. For scales, reliability coefficients higher than $\alpha=0.700$ are accepted to be high reliability coefficients (Özdamar, 2013). These sub- 
scales have high reliability levels. Spearman-Brown internal consistency coefficient found by dividing the test into two equal parts was calculated to be 0.928 . Thus, it can be argued that all the items in SICPS measure the same feature.

Table 3

Values of correlation between the Scientific Inquiry Competency Perception Scale total and sub-factors

\begin{tabular}{llllllllll}
\hline Factors & $N$ & $X$ & Ss & $p$ & Fak1 & Fak2 & Fak3 & Fak4 & Total \\
\hline Factor 1 & 100 & 18,99 & 3,36 & .000 & - &, $605^{* *}$ &, $526^{* *}$ &, $568^{* * *}$ &, $746^{* * *}$ \\
Factor 2 & 100 & 26,04 & 4,81 & .000 &, $605^{* *}$ & - &, $595^{* *}$ &, $603^{* *}$ &, $808^{* *}$ \\
Factor 3 & 100 & 18,51 & 3,72 & .000 &, $526^{* *}$ &, $595^{* *}$ & - &, $631^{* *}$ &, $787^{* *}$ \\
Factor 4 & 100 & 58,38 & 10,41 & .000 &, $568^{* *}$ &, $603^{* *}$ &, $631^{* *}$ & - &, $926^{* *}$ \\
Total & 100 & 121,92 & 18,97 & .000 &, $746^{* *}$ &, $808^{* *}$ &, $787^{* *}$ &, $926^{* *}$ & - \\
\hline
\end{tabular}

$* \mathrm{p}<.01$

**. Correlation is significant at the 0.01 level (2-tailed).

When the correlation coefficients for the scientific inquiry competency perception scale given in Table 3 are examined, it is seen that the correlation between the first factor and the second factor is .605 , the correlation between the first factor and the third factor is .526 , the correlation between the first factor and the fourth factor is .568 , the correlation between the first factor and the whole of the scale is .746, the correlation between the second factor and the third factor is .595 , the correlation between the second factor and the fourth factor is .603 , the correlation between the second factor and the whole scale is .808 , the correlation between the third factor and the fourth factor is .631 , the correlation between the third factor and the whole scale is .787, the correlation between the fourth factor and the whole scale is .926 . It is seen that there are significant medium and high level correlations between the factors. These values can be regarded as the evidence indicating that the scale items are subsumed under four independent factors.

\section{DISCUSSION AND CONCLUSION}

In the current study, the purpose was to develop a reliable and valid scale to determine post-graduate students' scientific inquiry competency perceptions. At first, the draft scale consisting of 71 items was administered to 100 students and then exploratory factor analysis was conducted on the collected data and 39 items with factor loadings lower than 0.30 were discarded from the scale and thus a total of 32 items having item total correlations varying between 0.423 and 0.784 were kept in the final form of the scale. These 32 items were found to be subsumed under four factors.

The first sub-dimension is comprised of items A1, A6, A7, A9, A10. This subdimension is for determining post-graduate students' perception of the competency for expressing the research problem.

The second sub-dimension consists of items B10, B11, B13, B14, B15, B20, B21. This sub-dimension aims to determine post-graduate students' perception of the competency for developing a measurement tool to conduct a study. 
The third sub-dimension includes the items B26, B27, B28, C3, C5. This sub-dimension intends to determine post-graduate students' perception of the competency for conducting data analysis.

In the fourth sub-dimension called Reporting, the items ARY1, ARY2, ARY3, ARY4, ARY5, ARY6, ARY7, ARY8, ARY9, ARY10, ARY11, ARY12, D2, E2, E3 are included. This sub-dimension elicits insights about post-graduate students' perception of the competency for reporting research results.

When the literature investigating scientific research is examined, it is seen that it mostly focuses on the determination of students' attitudes towards scientific research. The number of studies conducted in Turkey in relation to scientific research competencies is quite limited. In a study called "Elementary School Teachers' Scientific Research Competencies" by Büyüköztürk (1999), seven basic competencies that should be possessed by elementary school teachers were determined. A five-point Likert type scale was administered to the teachers to determine the extent to which they possess these competencies. As a result of the factor analysis, it was determined that this scale is a single-factor scale. This single factor explains $60 \%$ of the total variance and factor loading values range from .66 to .84. Alpha internal consistency coefficient calculated for the reliability of the scale was found to be .89 . Item analysis results revealed that item total score correlations vary between .55 and .77 . These findings concur with the item total correlations of the scale developed in the current study.

In another study called "The Opinions of Faculty Members about the Research Competencies of Post-graduate Students in the Field of Educational Sciences" by Büyüköztürk, Köklü (1999), it was aimed to determine post-graduate students' research competencies in the field of educational sciences. In the study, as a data collection tool, "Research Competency Scale" developed by Büyüköztürk (1966) was employed. For the whole scale, Alpha reliability coefficient was found to be .96 and for the five factors defined by factor analysis, it was found to be ranging from .87 to .92 . The scale is comprised of a total of 33 competency statements and 6 of these statements are related to problem identification, 5 of them are related to literature review, 9 are related to methodology, 6 are related to findings and interpretation and 7 are related to reporting. This scale is in compliance with the scale used in the current study in terms of the subdimensions.

In the attitude scale reliability and validity study conducted on the study by Korkmaz et al. (2011), it was found that The Scale of Attitudes towards Scientific Research consisting of four factors and 30 items is a reliable and valid scale to be used to determine attitudes towards scientific research.

In a work written by Erdem (2012) "Research Education in Training Scientists", while the question of what kind of education should be given while training scientists is answered, the competencies to be possessed by the scientist are also identified: explaining the problem statement, setting the goal of the study, reviewing literature, determining the research method, determining research model, selecting the population and the sampling, finding or developing data collection tools, collecting data, expressing 
research findings, analyzing and interpreting the data, reporting the research findings to the concerned parties and turning the research into a thesis, report, article or book. These competencies cover the competencies involved in the scale developed in the current study.

As a result of the validity and reliability studies conducted on "Scientific Inquiry Competency Perception Scale", it was found that this scale consists of four factors and is a reliable and valid scale $(\alpha=0,958)$ that can be used by future studies to determine university students' perceptions of scientific inquiry competencies. The scale is believed to offer guidance for further studies to be conducted in Kazakhstan and thus contribute to the literature.

\section{REFERENCES}

Akgül, A. (1997). Tıbbi araştırmalarda istatistiksel analiz teknikleri. Ankara: Yüksek Öğretim Kurulu Matbaası.

Boudah, D.J.(2011). Research in education, conducting educational research conducting educational research guide to completing a major project. SAGE Publications, Inc.

Büyüköztürk, S..(1999). İlköğretim okulu öğretmenlerinin araştırma yeterlikleri, Kuram ve Uygulamada Eğitim Yönetimi, 18,257-269.

Büyüköztürk, Ş., Köklü, N.(1999). Eğitim bilimleri alanında öğrenim gören lisansüstü öğrencilerinin araştırma yeterlikleri konusunda öğretim üyelerinin görüşleri, Eğitim ve Bilim,23(112), 18-28.

Büyüköztürk, Ş. (2013). Sosyal bilimler için veri analizi el kitabı. Ankara: Pegem Yayıncilik

Cohen, R.J. \& Swerdlik, M.E. (2013). Psikolojik test ve değerlendirme, testler ve ölçmeye giriş (Psychological testing and assessment, an introduction of test and measurement) (Çev.Ed. Ezel Tavşancıl). Ankara: Nobel Yayıncılık.

Creswell, J.W.(2012). Educational research, University of Nebraska-Lincoln: Pearson.

Crocker, L. \& Algina, J. (1986). Introduction to classical and modern test theory. CBS Collage Publishers Canpany. USA

DeVellis, R.F. (2014). Ölçek geliştirme, kuram ve uygulamalar (Çev.Ed. Tarık Totan). Ankara: Nobel Yayıncilık.

Erdem, A.R.(2012).Bilim insanı yetiştirmede araştırma eğitimi, Yükseköğretim ve Bilim Dergisi, 2(3), 166-175.

Kaptan, S.(1993). Bilimsel araştırma ve istatistik teknikleri, Ankara: Tekışık Web Ofset Tesisleri.

Kart, A.\& Gelbal, S.(2014). Öğretmen Adaylarının Bilimsel Araştırma Öz Yeterlik Algılarının İkili Karşılaştırmalı Yargılar Yöntemiyle Belirlenmesi, Eğitimde ve Psikolojide Ölçme ve Değerlendirme Dergisi, 5, (1), 12-23. 
Korkmaz, Ö., Şahin, A., Yeşil, R.(2011). Bilimsel araştırmaya yönelik tutum ölçeği geçerlilik ve güvenirlik çalışması. Elementary Education Online, 10(3), 961-973, 2011.

MacCallum, R.C., Widaman, K.F., Zhang, S., \& Hong, S. (1999). Sample size in factor analysis. Psychological Methods, 4(1), 84-99.

Morrell, P.D.\& Carroll,J.B.(2010). Conducting Educational Research (A Primer for Teachers and Administrators), Rotterdam: Sense Publishers.

Özdamar, K. (2013). Paket programlar ile istatistiksel veri analizi (9. Baskı). Eskişehir: Nisan Kitabevi, Cilt:1.

Sapnas, K.G. (2004). Letters to the Editor: Determining adequate sample size, Journal of Nursing Scholoship, 36(1),4.

Sapnas, K.G. (1999). Assessing the reliability and validity of the driving practices questionnaire in a sample of Hispanic south Florida drivers. Doctoral dissertation, University of Miami, Florida.

Sapnas, K.G.,\& Zeller, R.A. (2002). Minimizing sample size in exploratory factor analysis for measurement. Journal of Nursing Measurement, 20(2), 135-154.

Sadvakazkızı at.all. (2014). Eğitimde İlmi Araştırma Yöntemleri ve Eğitim Araştırmalarındaki Mantık, Young Scientist, Kazan. (III. Uluslararası Eğitim Kongresi, Çağdaş Bilim ve İnnovasyon Kongresi, Bolaşak Üniversitesi Kızılorda, Kazakistan Aralık, 2014. Özel Sayı),20.1, (79.1), 44-46.

Seçer, İ. (2015). Psikolojik test geliştirme ve uyarlama süreç, SPSS ve LISREL uygulamaları. Ankara: Anı Yayıncılık

Şeker, H. \& Gençdoğan, B. (2014). Psikolojide ve eğitimde ölçme aracı geliştirme. Ankara: Nobel Yayıncılık.

Taubayeva Ş.(2014). MMPI - 5207 Pedagojik araştırmaların metodolojisi ve metodtarı Dersi, Pedagoji ve Pskoloji Bölümü Sillabus , Al Farabi adındaki Kazak Milli Üniversitesi, Almat1.

Tavşancıl, E. (2005). Tutumların Ölçülmesi ve SPSS İle Veri Analizi. Ankara: Nobel Yayın Dağıtım.

Yaşar, M. (2014). Bilimsel araştırma yöntemleri dersine yönelik tutum ölçeği geliştirme çalışması: geçerlik ve güvenirlik. Eğitim Bilimleri Araştırmaları Dergisi - Journal of Educational Sciences Research,4,(2),109-129.

Yenilmez, K. \& A. Ata,(2012). "Matematik öğretmeni adaylarının bilimsel araştırmalara yönelik tutumlarının incelenmesi”, X. Ulusal Fen Bilimleri ve Matematik Eğitimi Kongresi, Bildiri e-Kitab1, 27-30 Haziran 2012, Niğde Üniversitesi, Niğde. 


\section{Turkish Abstract \\ Bilimsel Sorgulama Yetkinlik Algısı Ölçeği (Kazak Lisansüstü Öğrencileri Örneği) Geçerlik ve Güvenirlik Çalışması}

Bu çalışmanın amacı, Kazakistan'da eğitim bilimleri ve öğretmen yetiștirme alanında yüksek lisans yapan öğrencilerin yapacakları çalışmalarda kullanmak üzere bilimsel sorgulama yetkinlik algıs1 ölçeği geliștirmektir. Bu çalışma için betimsel yöntemler kullanılmıştır. Bu çalışmanın bağlamında eğitim bilimleri ve öğretmen yetiştirme alanında yüksek lisans yapan öğrenciler için bilimsel sorgulama yetkinlik algısı ölçeği geliştirilmiş, geçerlik ve güvenirlik çalışmaları yürütülmüştür. Çalışma 4 farklı Kazak devlet üniversitesinde eğitim bilimleri ve öğretmen yetiştirme alanında yüksek lisans yapan 100 öğrenci üzerinde yapılmıştır. Çalışmanın bulguları Bilimsel Sorgulama Yetkinlik Algısı Ölçeğinin (SICPS) 4 alt faktörden (Problem Durumu, Ölçüm Aracı, Veri Analizi, Raporlama) oluştuğunu göstermiş ve bu ölçeğin geçerli ve güvenilir bir veri toplama aracı $(\alpha=0,958)$ olduğunu, gelecekteki bilimsel araştırmalarda kullanılabileceğini ortaya çıkarmıştır.

Anahtar Kelimeler: bilimsel araştırma, yeterlik algısı, yeterlik, algı, algı ölçeği

\section{French Abstract \\ Échelle de Perception de Compétence d'Enquête Scientifique (le Cas d'Étudiants d'Étudiant de troisième cycle Kazak) Fiabilité et Étude de Validité}

Le but de l'étude actuelle est de développer une échelle fiable à être utilisé pour décider que la perception de compétence d'enquête scientifique d'étudiants d'étudiant de troisième cycle s'est engagée dans des études d'étudiant de troisième cycle dans le domaine des sciences éducatives et l'enseignement de professeur au Kazakhstan. L'étude a employé la méthode descriptive. Dans le contexte de l'étude, une échelle a été développée pour déterminer la perception d'enquête scientifique d'étudiants d'étudiant de troisième cycle du domaine de sciences éducatives et l'enseignement de professeur, alors il a été piloté et la validité et les études de fiabilité de l'échelle ont été conduites. L'étude a été conduite sur 100 étudiants d'étudiant de troisième cycle ayant l'enseignement post-universitaire dans le domaine des sciences d'enseignement et l'enseignement de professeur à quatre universités d'État Kazak différentes. Les découvertes de l'étude ont révélé que l'Échelle de Perception de Compétence d'Enquête Scientifique (SICPS) est comprise de quatre sous-facteurs (l'Énoncé du problème, l'Outil de Mesure, l'Analyse de Données, Rapportant) et est un outil de collecte de données fiable et valable $(a=0,958)$ qui peut être utilisé dans la recherche future pour déterminer des compétences d'enquête scientifiques.

Mots Clés: enquête scientifique, perception de compétence, compétences, perception, echelle de perception 


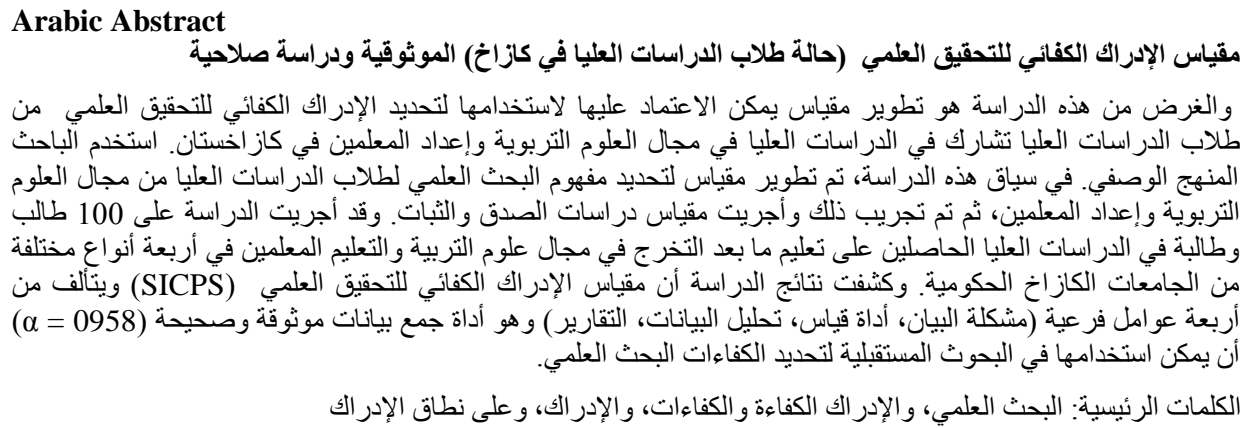

\section{German Abstract \\ Wissenschaftliche Untersuchung Kompetenz Wahrnehmung Skala (Der Fall der kasachischen Post-Graduate Studenten) Zuverlässigkeit und Gültigkeit Studie}

Der Zweck der aktuellen Studie ist es, eine zuverlässige Skala zu entwickeln, um die wissenschaftliche Untersuchung Kompetenz Wahrnehmung von post-graduierten Studierenden in post-graduierten Studien im Bereich der Erziehungswissenschaften und Lehrerbildung in Kasachstan. Die Studie beschäftigte sich mit der deskriptiven Methode. Im Rahmen der Studie wurde eine Skala entwickelt, um die wissenschaftliche Untersuchung Wahrnehmung von postgraduierten Studenten aus dem Bereich der Erziehungswissenschaften und Lehrerbildung zu bestimmen, dann wurde es pilotiert und die Validität und Zuverlässigkeitsstudien der Skala durchgeführt wurden. Die Studie wurde an 100 post-graduate Studenten mit post-graduate Ausbildung im Bereich der Bildungswissenschaften und Lehrerbildung an vier verschiedenen kasakischen staatlichen Universitäten durchgeführt. Die Ergebnisse der Studie zeigten, dass die wissenschaftliche Untersuchungskompetenz-Wahrnehmungsskala (WBW) aus vier Teilfaktoren (Problembeschreibung, Messinstrument, Datenanalyse, Reporting) besteht und ein zuverlässiges und gültiges Datenerfassungsinstrument $(\alpha=0,958)$ ist Kann in der zukünftigen Forschung verwendet werden, um wissenschaftliche Untersuchungskompetenzen zu bestimmen.

Schlüsselwörter: wissenschaftliche untersuchung, kompetenzwahrnehmung, kompetenzen, wahrnehmung, wahrnehmungsskala 


\section{Malaysian Abstract \\ Skala Kompetensi Persepsi Saintifik Inkuiri (Kes Kazak Pelajar Pasca Siswazah) Kebolehpercayaan dan Kesahan Kajian}

Tujuan kajian ini adalah untuk membangunkan skala yang boleh dipercayai untuk digunakan untuk menentukan kompetensi persepsi inkuiri saintifik pelajar pasca siswazah yang terlibat dalam pengajian pasca siswazah dalam bidang sains pendidikan dan pendidikan guru di Kazakhstan. Kajian ini menggunakan kaedah deskriptif. Dalam konteks kajian ini, skala yang telah dibangunkan untuk menentukan persepsi siasatan saintifik pelajar lepasan ijazah dari bidang sains pendidikan dan pendidikan guru, maka ia telah dipandu dan kesahihan dan kebolehpercayaan kajian skala yang telah dijalankan. Kajian ini telah dijalankan ke atas 100 orang pelajar pasca siswazah yang mempunyai pendidikan lepasan ijazah dalam bidang sains pendidikan dan pendidikan guru di empat universiti kerajaan Kazak yang berbeza. Dapatan kajian menunjukkan bahawa Skala Kompetensi Persepsi Inkuiri Saintifik (SICPS) terdiri daripada empat sub-faktor (Pernyataan Masalah, Alat Pengukuran, Analisis Data, Pelaporan) dan merupakan alat pengumpulan data yang boleh dipercayai dan sah $(\alpha=0.958)$ yang boleh digunakan dalam kajian akan datang untuk menentukan kecekapan inkuiri saintifik.

Kata Kunci: inkuiri saintifik, persepsi kecekapan, kecekapan, persepsi, skala persepsi

\section{Russian Abstract}

Компетентная Шкала Научного Исследования Восприятия (Пример Казахски Аспирантов): Исследование Надежности и Достоверносты

Компетентная Шкала Научного Исследования Восприятия: Исследование Надежности и Достоверности. (на примере магистрантов и докторантов Казахстанских ВУЗов) Целью настоящего исследования является разработка достоверного масштаба который дает возможность использования для определения научного исследования восприятия магистрантов и докторантов обучающиеся в области образовательных наук и педагогического образования в Казахстане. В исследовании применен описательный метод. В контексте исследования, шкала была разработана с целью определения научного опроса восприятия магистрантов и докторантов в области педагогических наук и филологического образования. Исследование было пилотируемый, достоверность и надежность исследования шкалы были проведены. Исследование было проведено в общем колличестве на 100 магистрантов и докторантов имеющих послевузовское образование в области филологического и педагогического образования в четырех различных Казахстанских ВУЗах . Результаты исследования показали что восприятие Масштаба Научного Исследования Компетентности (SICPS) состоит из четырех суб-факторов (Постановка Задачи, Инструмент Измерения, Анализ Данных, Отчетность) надежные и достоверные данные инструмента сбора $(\alpha=0,958)$ которые могут быть использованы в дальнейших исследованиях для определения научного опроса компетенций. Ключевые Слова: научное исследование, восприятие компетентности, компетентность, восприятие, восприятие масштаба

Ключевые Слова: научное исследование, восприятие компетентности, компетентность, восприятие, восприятие масштаба 